\title{
The Offensive Versus the Defensive in the Tactics of To-Day
}

\section{Captain Cecil Battine}

To cite this article: Captain Cecil Battine (1903) The Offensive Versus the Defensive in the Tactics of To-Day, Royal United Services Institution. Journal, 47:304, 655-672, DOI: 10.1080/03071840309417518

To link to this article: http://dx.doi.org/10.1080/03071840309417518

册 Published online: 11 Sep 2009.

Submit your article to this journal $\pi$

山 Article views: 10

Q View related articles 5 


\title{
THE OFFENSIVE VERSUS THE DEFENSIVE IN THE TACTICS OF TO-DAY.
}

\author{
By Captain CECIL BATTINE, 15th (The King's) IIussars.
}

THE bricf campaigns on the Tugela and Modder rivers, between December, 1899, and March, 1900, have brought about something like a revolution in the tactical ideas of the British Army. In the combats of December, 1899, on both lines of operation, our troops having a slight numerical superiority, were held up and bloodily repulsed by an enemy almost without military education, who defended prepared positions with dismounted cavalry, a form of action hitherto condemned as feeble. Trained staff they had none, their field artillery was much inferior to ours, and they had practically no organised supply system for movements on a large scale, or for keeping the field in any numbers at any distance from their base.

The arrival of large reinforcements turned the tide in our favour, but on both lines of operation the enemy succeeded in avoiding any decisive defeat in the open field, with the single exception of Paardeberg.

It is not to be wondered at that the success of these amateurs impressed the army of professionals opposed to them, and profoundly influenced the trend of military thought in this country. Indeed, the conclusion seems irresistible that if our leaders and troops did justice to their own methods, those methods must be essentially wrong, and the Boer riflemen, with their more desultory policy, their wide extensions, and indecisive action, better understood the offensive warfare of the future, while their plan of remaining on the defensive whenever possible must have incalculable tactical advantages over the attack:

The ablest contribution to the literature of the new tactics has, so far, been the modest volume by Major Callwell, "The Tactics of To-day." In its pages the most important developments in fighting which the war has brought home, and the new conditions in troop leading and troop training are clearly explained. The fact that this book has been generally used by officers studying for the entrance examination to the Staff College is a proof of the wide assent to its principles which exists in the Army. There are, however, in the field of modern tactics, many questions which at any rate are open to differences of opinion, and the discussion of which may be productive of some good.

Major Callwell gives the weight of his authority to support the theory which has gained formidable ground since.February, 1900, that the tactical defensive possesses inherent advantages over the tactical offensive (see pages 50,51 ), in contrast to the accepted doctrine which the leaders of the other Armies of the world take such pains to instil into their troops, namely, that to win you must attack. Offensive 
strategy entails offensive tactics, and to remain on the defensive is to suffer war, not to make it.

The most insidious danger which can beset an army is disbelief in its own offensive power. When once that opinion has permeated its officer corps, and soaked through its ranks, its days of conquest are surely numbered. It must take rank with Turks and Spaniards, whose valour no one questions, but whose empire is on the wane, who have ceased to be a terror to their neighbours, and who gradually lose their possessions as opportunity arises to attack them.

No alteration in the implements and machines with which war is made can affect that statement. Not only does the passive defence always end in defeat, but the most obstinately convinced partisan of a defensive policy is compelled now and again to attack in sheer selfdefence, both locally and on a large scale. The sorties of all besieged garrisons, and the attack which all armies are compelled to make to open certain roads and to prevent outflanking and surrounding movements of the enemy are cases in point.

The concluding paragraph of "The Tactics of To-day" begins thus: "Throughout this little work the endeavour lias been to show that one of the broad results of the improvements which have taken place of late years in the guns and small arms with which civilised States provide their military forces is to increase the power of the defensive." But, "few poisons are without their antidote," and the deadly effect of a skilful offensive in tactical action has certainly not become less with the improvement of weapons. Its successful execution demands a corresponding skill in leaders, superior and subordinate, higher training of the troops, and a more profound knowledge of the craft of fighting, just as any improved machinery requires a more skilled mechanic to obtain its best results. Recent wars have proved that to assume the offensive with troops and leaders who are below this standard of efficiency is to court disaster, even when a great numerical superiority is on the side of the attack, and when the enemy is in no condition to strike back with power. If, lowever, that superiority of shill and combination exists, the result of offensive operations is decisive in proportion to the destructive agencies employed.

The victories of Moltke are the most striking exemplifications of this theory, but other wars which have taken place in the last forty years bear it out, and the war with the Boers is no exception.

Before proceeding too far in the direction indicated by the latest tactical reforms, it would be as well to remember that however obsolete the former methods of warfare may have become, yet thcy never had a fair chance either on the Tugela or the Modder. In the battles of Colenso, Spion Kop, Magersfontein, and Pardeberg, the cardinal principles of offensive tactics were set at nought. These principles are laid down in our text-books as rell as in those of the Continental Armies. Indeed, it was easy to see that the authors of the text-books were, in theory, a very long way ahead of the officers charged with the task of teaching the troops. It may even be said that in the great majority of cases these officers belonged to an entirely different school of tactical ideas, completely out of sympathy with the text-book, the intentions of which, therefore, never had a fair chance of being accomplished.

It may be that the soundest application of former theories would have failed against the better rifle, and in the teeth of the far greater 
change effected by smokeless powder, but it cannot be disputed that failure is also the logical result of other causes.

It is now generally admitted that the tactical training of all three arms before the war was unsatisfactory, and to a great extent misleading.

The service of information lias now become far more difficult than formerly; it has almost become an art in itself. Everyone knows how little we understood about it before the war.

In the necessary mobility for successful attack, in the cohesion. and combination not only between the three arms, but different units of the same arm, we failed lamentably; and, most important of all, our system of command in the fight itself broke down at the most important crisis of the war. Admitting these facts, it is wise to hesitate before we discard wholesale the lessous and experiences of the wars which preceded 1899.

There is yet one other factor of cardinal impartance in the conduct of successful attack, and that is the grim necessity of sacrificing the lives of your men. No great result has ever been obtained over a determined enemy without incurring that penalty, and the whole course of military history enforces this sad lesson. The gift of military genius consists chiefly in knowing when and at what point the sacrifice will result in advantages morc than compensating the loss of life. Now, special circumstances held the hauds of the generals in South Africa. The great distance from all points whence reinforcements could be drawn, the small totals of our armies, the vast size of the theatre of war, the hostile populations all round our columns, the uncertainty as to the resources of the enemy, and the necessity for maintaining prestige in an Empire like ours and the consequent fear of risking too much at a single throw,-all tended to interfere with the purely tactical necessities of the case, and on more than one occasion robbed us of the fruits of victory which were just within our reach if we lad pushed on.

It may have been, too, that a long series of victories over savages, which were won at trifling cost of life, and the expectation of the public at home, who drew their opinions of the war from more or. less ignorant correspondents in the field, interfered to a disastrous extent with the decisions of our leaders. It must not be forgotten that the Armies of Britain and the United States had not only to face smokeless powder, but also the war correspondents. However wholesome may be the result of subsequent publicity of warlike operations, the presence of amateur historians and critics in the field itself is an additional and grave handicap to any leader, who is forced to take count of their reports, instead of bending his whole intelligence to the military aspects of the situation.

A reverse, to use the term which became unpleasantly familiar in the winter 1899-1900, came to mean an action in which the British lost more men than their opponents. Judged by this standard, the battles round Metz, on the 16th and 18th August, 1870, were colossal reverses, but the result of these battles not only decided the war in Germany's favour, but made her the principal State on the Continent for thirty years.

These considerations, the tactical and organic unreadiness of our Army for war, and the reluctance of our generals to hazard all their resources at the crisis of the campaign, are the most weighty in accounting for the comparative failure of our arms; but a number of 
others are easily brought forward which render the late war different to any other probable one; such as the nature of the country, the novel tactics and armament of our foes, and so forth.

With regard, however, to all such reasoning, it should be remembered that every war"teaches fresh lessons and has its own surprises, and a sound tactical training and organisation is precisely that which is able to face the unexpected and triumph over crude methods and impromptu levies. Moreover, less than any Army in the world is ours able to foresee with whom it will next be at war and to prepare deliberately to defeat the well-known methods and resources of one marked-down enemy.

Some advantages the Boers undoubtedly had which it is inconceivable would be enjoyed by a great military Power, European or American, in the elasticity of their lines of operation and their consequent ability to choose the fields of combat. They fought when and where they pleased, and retired across a whole province when they wished; they had over us the same strategical advantages which Napoleon's enemies put to. such good use in 1812 and 1813 ; but an Army which had to-morrow to bar the road to Berlin from the Vistula, to Paris from the Moselle, or to London from Colchester, could not make a present of a single yard of soil.

It would be out of the question to abandon fortresses and territories and important centres of population, and impossible to disperse the defending forces with a view to their resurrection in arms at an early date.

The same as regards tactics. The Boers would only stand to fight in large or small numbers when the ground or other circumstances gave them substantial advantages, but in the war of to-morrow we must expect to see the field disputed step by step. Our next enemy will not consist entirely of cavalry, and will not therefore be able to ride away so soon as he has liad enough of the fight. Retreat in the face of a victorions enemy who has come into close action with the vanquished will be a most difficult task.

On the other hand, a military Power will not hesitate to expend its troops. More men in attack and defence will be allotted to the ground, attacks will be pushed lome and repeated with far less regard to loss than was evinced by the Boers. The offensive will be more often assumed; that being the fundamental creed of modern military science. Close and shock action from infantry and cavalry, supported by a far more formidable and better directed artillery than that of the Boers will certainly be used against us, and these means of offence will be controlled and directed by leaders whose technical training has been thorough, and who have been carefully chosen in the Armies against which we are likely to be engaged.

Organisation of British Infantry Unsuitable to Tactical OfFensive.

Perhaps the greatest handicap under which our infantry labours, in comparison with foreign troops, is its battalion organisation.

The Armies of Europe, without exception, have made the company numbering about two hundred men on the battle-field, the principal executive and administrative unit. The commander of a company is really, and not only theoretically, responsible for his com- 
mand. He trains, administers, and leads them in peace and war. He excrcises more power over them than a battalion commander does with as, and his personality is the mainspring of the company's activity. This unit is the largest which can be directed by one man in a fight, and is large enough to carry out an independent task and to make itself felt. Four such companies make a battalion, and twelve a regiment.

In the British Army the battalion of eight companies corresponds organically to the Continental regiment, and as a tactical unit to the Continental company. This organisation labours under the disadvantages that its companies are too small for independent enterprise, and the company leaders, not having wielded executive authority in peace, are gravely handicapped by having it suddenly thrust upon them in war without previous experience; yet this is what necessarily happens, since it is impossible for one man to direct eight luundred in action. A number of untoward incidents lave made this fact clear. The proposal to break up the battalion practically into two fighting units is some recognition of the real state of the case; but the Continental plan is superior, and to stick to our own metlod, in spite of the grave disadvantages, is not unlike making the horse push the cart instead of pulling it. Moreover, the necessity exists for a permanent cadre larger than the battalion.

Closely allied with the tactical organisation of Continental. infantry is the method of handling its component parts in action.

Instead of that most disadvantageous formation, the quarter column, the rendezvous formation is the same as our cavalry employ, i.e., a line of company columns massed at close interval. The captains are mounted, and their companies are deployed for action as required, but the fundamental principle is observed of fighting from depth in cach company. . To each company leader is a separate task assigned, and each retains his own reserve in hand so long as he thinks fit, gradually using up his command in pushing forward, in contrast to. the plan of thrusting whole units in widely extended order straight into the fighting, when all concerted direction ccases under moderate fire.

A number of fights in South Africa showed that, with the bravest troops, these tactics of ours frittered away our strength in indecisive action, and bootless success when eventually we did capture the hostile position.

It is the fashion to talk of a frontal attack as a blunder, but. without frontal attack there is no such thing as decisive action. The most successful turning movement depends for its result on the enemy being lield in front, and an enemy must be foolish indeed if he allows himself to be outflanked unless he is pressed so hard in front that he caunot shake of his adversary. A flank attack must generally be locally a frontal attack, and if too wide an extension be made to deliver it, the risk is run of the defender assuming the offensive with deadly effect against the outflanking troops while weakened by wide extension.

Liberties were taken by the Boers in this respect which would probably have been severely punished by a Continental Army, because the Boers themselves did not venture to attack, but. on such experiences as the advance from Bloemfontein to the Vaal it is extremely rash to build up a tactical system.

vol. XLVII. 
The most brilliant instance of a flank attack on a great scale in modern military history is the battle of Chancellorsville. But the Army of Northern-Virginia was led by three generals, to each of whom the term military genius may be ascribed without flattery. Tts movements were concealed by forests, and its opponents were indiferently commanded. When Lee attempted to repeat the performance at Gettysburg, after Jackson's death, by falling on the Federal flank and rear with Stuart's cavalry, the blow missed its object, owing partly to the wide disconnection of the troops to whom the enterprise was' assigned from the main body whose attack they had to assist. Yet the Gettysburg campaign was fought on a far smaller theatre than would be a struggle between two great military Powers with the weapons of to-day.

The type of attack exemplified by UIm, Sedan, and Paardeberg, the complete re-investment of a field army is now, as formerly, the most complete tactical victory which can be obtained; but it requires a great preponderance of strength on the attacking side. The next best plan for the destruction of a hostile army is to cut in between its wings and compel its troops to retreat under the fire of the successful assailant. Of course, the flank attack must, whenever possible, be combined with the frontal one; but unless the area of the battle-field is small enough to admit of the points attacked being under fire from two directions at the same time, the actual effect of the flank attack will be comparatively local.

As an illustration of this plan of attack the battle of Spion Kop is rich in lessons.

Our troops, by a successful frontal attack, drove a wedge in the enemy's line at night. The advance was, by an error, stopped too soon, and the attacking troops at dawn found themselves exposed to enfilading fire and enveloping attacks which were pressed to close action by the Boers, almost to hand-to-hand fighting.

Nevertheless our attacking column, now thrown on the defensive, held its ground and drew on itself the best part of the enemy's troops. Within reach of tactical action, on both flanks of our column, were present on the field enough British troops to have given us a decided superiority in the battle. Had these troops been sent. forward to the last man to the help of the comrades already engager there can be little or no doubt that the enemy, weakencd and dispirited, would have been compelled to retreat across the comparatively open ground which lay between Spion Kop and Ladysmith, within range of our rifles, and with the garrison of Ladysmith on its line of retreat. The most important battle of the Boer war may fairly be claimed as conclusively proving the necessity of grasping the nettle and the absolute impossibility of winning decisive tactical success without doing so.

\section{A Classification of the Methods of Attack in the Field.}

Having arrived at the conclusion that the bull must be taken by the horns, the next question is: how best to do it?

1. There is the plan of shooting an enemy out of his position. Perhaps the most remarkable lesson of the Boer war has been the extreme difficulty of driving an enemy from his ground by fire action alone. Determined troons, protected ever so little by natural or 
artificial cover, can, as a rule, only be conquered by this method if it is combined with enveloping and surrounding movements.

2. There is the approach by sap, successfully adopted by our troops at Paardeberg. It was frequently used in the American Civil War, and will no doubt be often seen in the future. In other words, it is the plan of treating a defensive position as a fortress, hastily erected, but sufficiently strong to require the methods of fortress warfare.

3. Night attack. The Boer war abounds in examples of night attacks, both successful and otherwise. The advantage to the assailant is penalised by the difficulty of mancuvring and leading in the dark, and none but well-trained, brave troops, with the most advantageous tactical organisation, need expect to win much by a night attack on a big scale.

- The capture of Kars by the Russians on the night of November 15th, 1877, is an example of what can be done by troops who possess these qualifications. The Russians moved from their trenches at 8.30 p.m. The Turks opened fire at 9.30 p.m. By 5 a.m, November 16th, a modern fortress had been captured after fierce hand-to-hand fighting, and with a loss of two thousand three hundred killed and wounded to the victors.

4. Here we reach the point at issue, viz., the attack by day; is it feasible in the teeth of modern armament, and, if so, how should it be attempted? Admitting that the rifle and ammunition of to-day can hold good an open field of fire, we must yet remember that no position with over a running mile of front will be without undulations, woods or buildings to spoil its glacis, and which will permit of an attack at close quarters, and even hand-to-hand, from troops who have been taught to use their shelter. Moreover, no defensive line is quite straight, and opportunities occur of locally outflanking. Troops will only be able to advance by most skilful use of any protection the ground may give, and by the covering fire of their own side.

It is also absolutely necessary to the success of the attack that the defenders' line of riflemen should be approximately located, and this can only be done by most careful and skilful reconnaissance by trained scouts. The scouts of the attacking side must literally stalk the defender, and this is just as necessary in any one of the first quoted plans of attack, or in any combination of them with the last.

An attack on an army which has taken up a defensive position by day, without counter entrenchments, pre-supposes then a normal field of battle, which while giving the defender a good field of fire, is not without accidents of ground, and capable of sheltering the attacking riflemen.

Theso must consist of two distinct divisions.

The first will seize a position as near as possible to the enemy's position, from whence it will keep the whole defending line under fire, and will be able to beat with a ceaseless pelt of bullets the spot selected for the charge of its own stormers.

This point will of course be made doubtful to the defender as long as possible. He must be menaced the whole length of his line so far as possible, It may be necessary even to sacrifice troops in a false attack to deceive him, and such false attacks may sometimes be successfully pressed home. The actual goal of the stormers must be so completely swept by rifle fire up to the last moment that the exposure of an eye or a finger in taking aim should be a serious risk to the 
defending troops. Single riflemen should crawl up in advance of the firing echelon, endeavour to pick of the defenders' boldest men, and directing leaders. The Victoria Cross could not be more suitably awarded than for effective service of this sort.

The enemy's line of riflemen having then been located, and its neighbourhood smothered with bullets, the most. difficult part of the task remains to be done, namely, the advance of the storming party or parties. In the teeth of smokeless powder and the rifle of to-day in the hands of a determined adversary, there is but one plan for bringing up your men to within charging distance, lowever well covered by the fire of their comrades, and that is the plan long practised in the French Army, and known as the advance by petits paquets. Attacking infantry can no more advance to within a hundred yards of a position at ten paces extension than they can in line of company columns, and, if they could, they would probably effect nothing when they got there. The formation of the advancing infantry in petits paquets depends'absolutely on the lie of the ground, which has, at any cost, to be reconnoitred before the attack. Handfuls of men are brought over the fire-swept area, regardless of formation, either crawling or rumning, or marching in step, in whatever way the enemy's fire permits. Every inch of ground within charging distance of the point of attack which is in any way sheltered from fire is filled with troops. Directly the signal to charge is given, a simultaneous rush takes place, and supporting troops must follow as close as possible on the heels of the first echelon of the attack.

The assistance in this manœuvre which infantry demands from its artillery is that the ground in rear of the defending riflemen should be effectually shelled, so as to kill their horses or ponies, if they consist of cavalry, stop their supports from helping them, and giving them anxiety as to their own chance of retreat from the advancing swarm of bayonets.

To shell men out of cover, be it ever so light, has been proved to be a very difficult matter.

The shape then that the infantry attack of to-morrow is likely to take is well represented by the Roman gladiator with his net and trident. The enveloping net of the skirmishers and firing parties must cling closer and closer to the hostile position until the stormers have reached their goal, when they should immediately open out, take what cover they can, and follow up their success by fire action.

The experience of the last and other recent wars goes to prove that attacks made on these principles, and by troops who thoroughly understand what is intended, will usually succeed. What is more doubtful and harder to foresee is this: When the wedge has been driven into the enemy's line, will it bccome a shot-trap like Spion Kop, or will it dominate the enemy's position, sever his forces, and compel his retreat under fire, as the capture of the Niederwald pierced the defending line at Wörth, the Rotheburg at Spicheren, and as the apture of the Bois de la Garenne forced the French defensive line sovering Sedan?

Generally, in the case of serious attacks, the troops told off to torm the position should not open fire until they have thus accomjished their first mission. Their fire will not injure the enemy much, ut it will expend ammunition, which may be worth its weight in gold in hour later. The act of firing also gives an excuse for holding on 
to captured ground instead of advancing further, and at close range: reveals the position of the attacking column, and exposes its mes. while taking aim.

The word columr, indeed, more exactly describes the formation of. the assailants: they should pour like a river into the defender's position along the line of most cover. If the old attack formation resembled the advancing tide, the new one will recall a number of parallel or converging streams rushing forward, as the surface of the ground permits.

\section{The Influence of Woods on the Battle-Field.}

Woods are rarely absent from the battle-fields of Europe. an America, and more than any ather accident of ground they favour the attack over the defence. In South Africa, they were scarcely ever found, and that in itself gives defensive tactics in that country an advantage they would not have elsewhere. A long list of battles instantly occurs to the student of military history at which the woods have covered the dispositions of the assailant, have marred the symmetry of a defensive line, and often enough caused its ruin. The American Civil War was rich in examples of woodland fighting, and the great leaders of the Army of the Northern Virginia gave many a lesson of how to turn to account the friendly shade of the forest in preparing and dealing the most stunning offensive strokes, and also in the defensive tactics which most effectually check and harass an attacking enemy.

The cdge of a wood forms the most tempting target for attacking artillery, which, if the wood is of any size, can with difficulty be met 'by the defenders' guns. A zone of some hundred yards in breadth -can be rendered untenable and, unless the defending infantry have had leisure to erect extensive obstacles within the wood itself, the assaulting troops can come to close quarters under circumstances which are all in their favour. The one essential is a sound tactical system of leadership, so that the captains of companies may be able to carry -their men along with them in spite of the confusion incidental to forcing a way through the wood. It was their superiority in this respect which decided the wood fight in favour of the Prussians at Sadowa.

$A$ wood once captured, its value as a starting point for fresh -enterprises will, of course, depend on the ground beyond it, but useful it must be to conceal and protect the concentration of attacking troops, and will very often enable them to penetrate and sever the hostile position.

It is the fashion to sneer at the plan of studying the battle-fields and records of the Franco-German war. No greater mistake could be made. Whatever we have just learnt as the result of our own recent experiences, the war of 1870 still remains the most important and in many ways the most typical instance of modern warfare, and no one who has not made himself acquainted with the great fights round Metz, and the ground upon which they took place, can claim to be abreast of modern military science. That, at any rate, is the thorough conviction of the leaders of military thought on the - Continent.

The struggle for the possession of the ridge from St. Privat to Point du Jour is the principal example of offensive tactics carried to 
successful and decisive conclusion in spite of calamitous errors and heavy loss of life. Throughout the day the curtain of roods which hung round the French left, and hid their adversaries' movements, exerted a decisive effect in detaining the French reserves on this flank, and thus rendering possible the turning movement against their right. The wooded sides of the Mance valley enabled the assailants to hang on to ground from which they would otherwise have assuredly been driven pell-mell, and repeatedly carried their fighting line to within charging distance of the enemy's rifles. The picture of the 'mixed mass of German foot soldiers cowering behind the narrow shelter of St. Hubert, less than 300 yards from the foe, suggests that had the dispositions for attack here recommended been adopted, had this large force reached St. Hubert by design, in good morale, and, unshaken by losses, which were palpably the result of faulty leading, instead of drifting thither panic-stricken, and in defiance of their leaders, the final and decisive spring might have been made from that point as. well as from others further to the Erench left.

The frontal attack on St. Privat would certainly have resulted in destruction had the defenders been armed as we are at present. Nor would the successful advance up the railway, which was really decisive of the day, have been possible; but the proposal of the commander of the Third Corps to cut the French Army in two by the capture of La Folie copse on the crest of the narrow ridge, would now, as then, be possible, if executed under the best conditions.

Until the fate of a war is decided by such another battle, fought out to a finish, between rivals of such military value as faced one another on the 18th August, 1870, it is sheer folly to throw its lessons. over in favour of a system of tactics which, at best, has produced desultory fighting and indecisive success.

A point of supreme importance in deciding whether or no a frontal attack on a defensive position is possible must be, of course, the length of time the defenders. Inave had to entrench it, and their aptitude for doing so. The. Boers and Turks displayed unusual cunning and energy in this respect. The character of one's opponent has, therefore, to be considered, the probability of his being well provided with entrenching tools, as well as his intention of standing to. fight. An army with a large proportion of infantry will rarely expend its energy in digging unless the plan has been made to defend a particular position.

After the battle of Spicheren, the Army of the Rhine successively entrenched and abandoned positions at St. Arold and on the French Nied, and were eventually to meet attacks in the open at Borny and Vionville, while at Gravelotte and St. Privat the natural strength of the position had been but little improved by entrenchment.

Has the enemy planned a defensive action on this ground? Has. he had one hour, or six, or twenty-four to prepare for it? These are questions of no less interest than the others to be answered by the attacking general.' How near can I get my troops to the position unseen by the enemy? Is there a salient in his line which can be enfiladed? What flaws do the accidents of the ground make in his. field of fire?

The picture which is readily called up to the imagination by the term frontal attack is that of which Colenso and Paardeberg may be: 
said to be typical. Gallant troops, unable to retaliate on the hidden foe, shot down by hundreds, until they are sullenly compelled by the murderous fire to give way.

There is, however, a l'everse to the medal.

Let the reader imagine limself to be serving in a battalion to which is confided the defence of an important section of a position.

The ground in front of the position slopes gently away, and for about half a mile or more is open and marked by few undulations. Here and there a low straggling fence, with a shallor, ditch, slightly obscures the commanding view from the defended crest. Parallel with the front runs a little stream. In the hasty reconnaissance which has preceded the occupation of the ground, it has hardly been grasped how important this bit of the line may be, with the wooded slopes in rear of it, connecting, as it does, a village prepared for defence and an entangled copse, and curving outwards slightly in the direction whence attack may come. The battalion has marched several miles in that grey of the morning before taking up its position, and its breakfast has been of the scantiest. The weatlier is cold, and the rain falls in sharp, slanting squalls in the men's faces.

Only a few picks and shovels are available. With these, lowever, strenuous efforts are made to improve the slight cover offered by a stone wall and a rambling fence on the crest of the ridge.

Three hours after, the battalion has quitted its bivouac in the . rain, the first shells are fired from unseen guns. Gradually the fire increases and extends. Shells fall on the ridge, and tear up the brushwood on its reverse slope. The men take what shelter they can, holding the defensive line with a few rifles.

By and by the opposing infantry can be seen, and are fired at; for some time there is no reply. Another hour has passed, a small number of casualties have occurred, ghastly wounds inflicted by shell. Presently the hum of bullets becomes perceptible, the enemy's skirmishers are still pressing forward, and some few of the most daring have actually reached the banks of the little stream, and found precarious cover.

During the next half-hour the intensity of the assailants' fire increases, while it is evident that the troops to the right and left are engaged up to the hilt. The whole ridge is alive with bursting shell; shrapnel falls in showers belind the crest, driving back the companies in reserve, and stopping communication between them and the fighting line more or less. The latter has now to meet a perfect sleet of bullets, which come from more tlian one direction, while the enemy's skirmishers continue to press forward; it is also evident that small handfuls of men are rushing from one point of cover to another in spite of the spurt of fire which comes from the crest every time they are scen.

Still the advance continues, and the attacking infantry seem to sink into the ground in the intervals between the rushes. Bullets whip the ground in front and behind the crouching soldiers on the ridge; not a few are hit as they aim, and their firo sensibly slackens.

In another half-hour it is erident they will have to face the mad rush of the storming column, consisting of men who know that it is at least as dangerous to go back as to go forward. 
Whoever can in imagination realise this situation, and feel the terrors it is bound to produce upon the weary and weakencd men on the hill, will understand that all the chances of war are not against the bold and resolute assailant in the struggle for the key of a position.

\section{“The Tactics of To-day." The Chapter on Infanthy Tactics.}

In Major Callwell's book, the tactics of the attacking infantry are described and explained. He lays stress on the necessity for the company being the tactical unit, though it is clear from his proposal to extend one of our weak companies over two-hundred-and-seventy yards of front (the manner in which he proposes to distribute the battalion in action with five companies "in front line") that he is not weaned from the old idea of the battalion as the tactical unit.

To lay down rules for the extension of attacking infantry to a given number of paces is equally futile. The ground and the ground alone can determine how close to one another the men move and fight.

Major Callwell realises that if the charge is to be made at all it will "take place in a swarm"; though he seems to think that the thin scattered lines, who have skirmished their way from two thousand yards to this point, will close in on some sheltered spot to form this swarm, instead of merely demanding from this line of skirmishers to hold and occupy the enemy while a fresh echelon of troops, specially, led thither for the purpose, under the protection of their comrades" fire, delivers the rush with the bayonet. The first is linear tactics carried to extreme development, the latter depends for its effect on the advance, of a column protected by the fire of the skirmishing line, and recalls the system of attach employed by the French Revolutionary Armies, with the difference that the latter had no occasion to keep out of their enemies' sight during the advance.

The picture of several extended lines following one another at one hundred and fifty yards distance, and firing over one another's heads, drawn from the fights in South Africa, will sometimes be seen in the battle-fields of the future; but in England and on the Continent it will be the exception to find ground sufficiently open, and more often there will be, as of yore, but one skirmishing line, though, doubtless, fire will be maintained, by parties told off for the purpose, over its head from any point of vantage, while the supports and reserves will move in the folds of the ground, and remain in compact formation so long as any shelter from fire is to be obtained near enougl to the men whom they have to support.

The necessity for each company having the responsibility of covering its own advance with fire is insisted upon, but the proposed distribution of this unit in action would not facilitate the matter.

The rate of advance is touched upon, and it is rightly conjectured that "on ordinary ground, and in face of average resistance, the movement will usually take many hours in execution, from the moment when the adrance commences up to the crisis of the enterprise."

It was characteristic of our infantry attacks at the begiming of the war that the attempt was made to hurry them through in a manner which is impossible nowadays.

The pages devoted to the defence are for the most part admirable. and, indeed, it is preference for the defensive attitude, and belief in its superior strength, which is the basis of the author's creed. He 
may be right that "troops in elispersed formation are almost invalnerable against alirect attack if they hale a satisfactory field of fire," but on. this condition everything depends. Quite often enough for the purposes of the assailant, "the satisfactory field of fire" will be wanting, and there will occur the chance of ruining the defence, and of imposing upon it the will of the more enterprising side.

In contrast to the belief in the defensive rôle, which has now become fashionable, stand the "observations" which Sir Redvers Buller is reported to have made for the benefit of his Aldershot command on his return from the Natal campaign, the long series of offensive movements which carried his army from the Tugela into the heart of the Transvarl in the tecth of a stubborn enemy, and in spite of natural obstacles as formidable to an invader as ever were encountered by a large army.

His observations on infantry begin as follows:-

"The main lesson learnt in South Africa appears to have been that infantry can successfully attack almost any position, provided the attention of its defenders can be absorbed by fire directed by bodies of troops other than those engaged in the actual assault. The best method of arriving at this end is by the co-operation of the two or of the three arms; but if that caunot be secured a second body of infantry or machine-guns should be employed in a favourable position to pump lead upon the enemy while the attacking troops are advancing to the assault. In fact a position must be attacked by a combined movement rather than by a single movement." The case for offensive tactics on the ground could not be more forcibly given.

In the conclusion of Major Callwell's book, the chapter on the Principles of Attack, pages 27 to 30 , the difficulties of the attacking side are ably and graphically set forth, and the methods by which "the attack will in the immediate future gain the day in battle," namely, "by sweeping round the flanks of the enemy," by a process almost akin to sapping; the seizure of successive positions, and fortifying them till the enemy can be crushed by close range fire, or ousted by a sudden rush across a very short distance, "differ in no wise from the resources of the attacker above described." Another deduction, however, would be more correct from this "conclusion," and that is:-the troops which can by any means be compelled to move within reach of the enemy's fire suffer a grave disadvantage, and that may happen to the defender as well as to the assailant. The successful attack by the Third Prussian Corps on Bazaine's Army, moving from the Moselle to the Meuse, on 16th August, 1870, is not a more convincing proof of this than the ease with which General French headed off Cronje's retreat on the Modder banks, and brought it to a standstill.

It would seem from the result of these, and many other actions fought under similar conditions, that the great object of a general should be to compel his adversary to move within reach of attack, and it is clear that the only way to accomplish this end is to attack with resolution, as the Prussians did at Borny, Vionville, and Beaumont, and the Boers at Lombard's Kop and Nicholson's Nek, unless superior mobility enables the offensive to capture a defensive position which bars the enemy's further progress, and which cannot be neglected, as, for example, the investment of Bazaine by the Second 
German Army on the 19th August, 1870, and the heading off of Cronje at Paardeberg Drift by General French.

From many points of view the situations of Bazaine on the Moselle, and Cronje on the Modder, resembled one another, and if there be differences of opinion as to whether the attempt to storm the laager at Paardeberg Drift was necessary or not, there can be no doubt that their prey would have escaped the German Armies on the Moselle had they not been prepared to stake all on the tactical offensive. Had those Armies not penned in Bazaine by the capture of St. Privat, they never could have spared the three army corps from the Moselle, which completed the destruction of MacMlahon on the Meuse, nor in all probability would the latter have been driven into a comer on the northern frontier. The whole circumstances of the campaign would have been changed enormously in the favour of France.

\section{Mass Tictics.}

One of the most puzzling questions which the invention of smokeless powder has given rise to is this: to what extent have the new conditions of fighting modified former calculations as to the number of men per yard required for a reasonable chance of success both in attack and in defence; and although it is easy to be too pedantic in making such calculations, yet it is obvious that some basis for them must exist to enable commanding generals to dispose their forces to best advantage. At Gravelotte the Germans had more infantry and guns on the ground than they were able to deploy, and although this was to some extent the result of faulty direction of the marching columns, Moltke's one comment on the day's work as he drove back to Pont à Mousson, is said to have been: "One cannot be too strong on the battle-field."

At Plevna three important battles were fought over practically the same ground on a front of more than seven miles. On July 20th, the Russians disposed of six thousand five hundred men; on July 30th, thirty-five thousand men were engaged, and on September 11 th nearly one liundred thousand troops took part or supported the attack. The Turks received proportional reinforcements after each battle. The field of fire was excellent, and the Russians neglected what little cover they might have used in their advance. There can be no doubt that with smokeless ammunition the Turkish victories would have been far more complete. As it was, nothing but the astonishing mistakes of leadership and direction on the part of the Russians, on September 11 th, prevented their gallant infantry from capturing the Turkish entrenched position; and on both wings at Grivitza, and on the Green Hills, they actually drove the Turks beyond them with the bayonet.

Even after making due allowance for the changes in fighting caused by smokeless powder, the result of the battles of Gravelotte and of Plevna, September 11th, suggests the question of whether it may not still be possible for a bold and skilful leader, who is prepared to pay the price, to smash an enemy by violent and repeated attacks with superior numbers, after the methods of Moltke and Napoleon.

The invention of smokeless powder las unquestionably rendered a thin firing line of men as formidable at twelve hundred yards as three times their number were in 1870 and 1877 at five hundred yards, given an open field of fire: but the necessity for adequate numbers on 
the points of attack with the bayonet, of adequate supports to the rush of stormers, of sufficient men to replace the melting away process of skirmishing lines, which the last wars have proved to be so considerable even with the best troops, and, lastly, the necessity of replacing men who will become physically worn out by the length of the battles of to-morrow, render it dangerous to accept the theories of wide extension and the plan of trusting entirely to outflanking movements. Not only will the prey generally escape, but he will not infrequently turn the tables and ruin his scattered foes as he strikes back with sufficient determination, and is prepared to lose the same proportion of men as Marlborough, Frederic, Napoleon, Lee, and Moltke, all considered unavoidable and necessary to aclieve a great tactical victory by means of an offensive stroke.

It is, at any rate, more certain than ever that, with contemporary armament, the larger the armies engaged and the more important the issue to be decided on the field, the greater will be the number of men required per yard both in attack and defence; also it is probable that big woods and steep mountain country will swallow up almost as many troops as formerly; so that in handling large armies the calculations which held good in 1870 do not need to be so greatly modified to-day in deploying troops on the field of battle, as is popularly supposed.

\section{Defensive Armotr.}

Among the changes in armament which the near future is likely to bring about, and which, if successful, will largely increase the power of attacking troops, is the invention of defensive armour for the individual soldier. The fact that such armour has become gradually neglected since the invention of fire-arms is out-balanced by the urgent necessity for its re-introduction, and the use of shields on field-guns is likely to be the precursor of fresh expedients of the same kind. It is, after all, the rifle bullet which settles the fate of a battle to-day, and it requires neither, a very heavy nor a very large piece of steel to afford absolute protection from frontal fire to a soldier lying or crouching on the ground.

\section{Cavalry and Staff.}

There are two qualifications vitally important to an army which assumes the offensive rôle, and as war becomes more complicated these conditions become more indispensable.

The first is a superiority of cavalry over the enemy so as to forestall him strategically and tactically. The second is the possession of a system of executive command which ensures the harmonious and co-ordinate working of large masses of troops separated by great obstacles or by great distances in the crisis of a fight, when a constant flow of orders is impossible, and when a few well-chosen sentences must render intelligible to every subordinate leader the task he has to do. If we compare the marvellous precision with which Moltke directed his mighty columns of troops in 1866 and 1870 with the constant failure to strike together, which is remarkable in wars carried on by extemporised staffs with indifferent chiefs, we shall realise the importance of successfully solving this problem in peace. 


\section{Gavalry.}

The cavalry question is attacked by Major Callwell in his chapter on the "Tactics of Mounted Troops," and with his main conclusions I cordially agree. " For campaigns between great modern Armies mounted troops must consist of genuine horsemen who can wield the sword or lance with confidence from the saddle, but who regard the use of fre-arms on foot as their principal means of offence and defence"; also "it would be as unwise to deprive the trooper of the arme blanche as it would be to rob the infantryman of his bayonet. To attach undue importance to this secondary armament is as inexpedient in the one case as in the otler." "There will not be found many practical cavalrymen to dispute these opinions, but beyond then the common ground of agreement does not go far.

In the Boer war the greatest part of the mounted troops in our Army consisted of Mounted Infantry, Mounted Irregulars of all sorts, and Imperial Yeomanry. Now while the Regular cavalry officer may meekly admit every accusation that has been flung at his service by critics for the last three years, it is indisputable that the substitutions of these levies for a Regular cavalry force proved a costly failure.

Hardly a month passed by but some convoy or column was destroyed, whose patrolling was confined to these new-fashioned mounted troops. In our Regular regiments, whatever were the faults of their personal training and organisation, the country had the nucleus of a cavalry which might, with judicious re-organisation, have been expanded into a mounted force superior to any other in the world.

The opportunity was missed.

The irregular mounted troops, without any leavening of leaders or N.C.O.'s trained in the art of cavalry soldiering-and it is an art not to be learnt by an infantry soldier jogging round a riding school a given number of times-have never attained the standard of value necessary to compensate for the "outlay which their organisation demands, the strain which their forage throws upon the supply and transport services, and to repay the inconvenience which their movement by rail or ship entails."

Of course, in the war there have been corps of irregulars which have proved themselves brilliant exceptions, and corps of Regulars which have not done as well as others, but the main contention holds good.

When infantry are put on horseback they become cavalry. It is the possession of the horse and not of a fire-arm which distinguishes the two. It is the merest confusion of terms, a confusion which is very mischievous in military affairs to call such mounted troops infantry, whether or no the officers and men were drawn from infantry regiments. The point has far more importance to the future of our cavalry than most people imagine. Thc cavalry soldier requires higher training than infantry, both for leaders and for troopers. It is possible that the Armies of the future will consist of a very large proportion of cavalry, and when horses have been used up, ponies will be drawn upon to mount the troops. Since it is easier to ride a pony than a horse, less perfectly trained troops can have the ponics allotted to them, while the first line will have the horses.

Patrolling in concert against smokeless powder requires careful training, and so does fighting dismounted. A squadron which does 
its dismounted work intelligently and quickly will always be able to deliver a charge. Both on foot and on horse speed is the essential condition for success.

It may or may not be that the shock of charging squadrons is a thing of the past, bat two conditions are certainly essential to success if shock action is ever to be used:-

1. Every squadron within reach must be able to participate.

2. The cavalry must be able to deploy at an instant's notice, and form a charging swarm from column of route.

The reason for the first is that more than ever in the past halfhearted attacks will be worse than useless, and if part only of your cavalry is capable of shock action, it will probably not be they who are at hand when the one opportunity of the war occurs in which to deal a knock-down blow with sword and lance.

As to the second, these opportunities will be so fleeting, and the necessity for concealment up to the last moment so urgent, that no cavalry which cannot,stalk its enemy in a narrow column and deploy at speed into a series of supporting echelons will ever get a chance of striking with steel on horseback. Nothing could have been less like a cavalry fight with contemporary armament than the mancuvres and exercises we practised in the years which preceded the war.

Above all, cavalry must be fired with the spirit of restless offensive and restless curiosity. A book may well be written on the subject, and on the chances we have under existing circumstances of developing a cavalry force capable of taking the offensive in the next great war, and no one who has grasped the history of recent events can have any doubt as to the importance of the question.

\section{Conclusion:}

The tendency of military discipline is to make all Armies tenacious of tradition and opposed to change, and this, perhaps, is more marked in a democratic State like ours than in a military monarclyy like Germany, whose Army includes all the best intelligence and keenest critical talent in the country. Having. regard to the march of mechanical invention, and the consequent perpetual change in armament and tactics depending thereon, it is clear that we must be prepared to modify our tradition or be left behind.

We often hear it repeated that our Army gets more experience in figliting than any other, and it is doubtless true; but we should also remember that Armies accustomed to a long continuation of easy success have sometimes gone down before opponents whom they despised, but who have quietly and laborionsly perfected their forces in peace. No sensible man denies the use of experience in war, as in otler business, but experience of war is not confined to a single struggle, however novel, interesting and absorbing. To benefit by our most recent experiences we should compare them carefully and dispassionately with all the most reliable military records which modern wars have placed within our reach. Speaking generally, our officer corps, though well instructed in many respects, has neglected the study of history. Indeed, an officer can easily get his commission without any knowledge of the subject whatever, although he is crammed with academical knowledge liaving little or no practical bearing on his profession. The 
entrance examination to the Staff College includes some military history, but it holds a far less important place than in corresponding tests in foreign Armies. An enquiry into the subsequent study of this science in other countries, and the methods of teaching it in combination with other branches of military art, would show how much greater importance is attached to it in France and Germany-especially in the latter country-than in England.

An.Army in its system of training has to steer between the danger of encuuraging too much criticism, which may degenerate into cavilling at superior authority and ignorant fault-finding on the one hand, and on the other too much conservatism; the indolence of blind obedience, the reluctance to assume responsibility or initiative and that respect for routine as an end in itself instead of as a means among others to achieve great results. two.

Experience has shown that the latter is the greater danger of the

The former is a healthy symptom found in armies of volunteers and extemporised forces, whose zeal is greater than their knowledge, and which corrects itself with time. The latter, however, is a slow but certain poison which has ruined fine armies and brought down mighty States; and if it had this result in the days of Austerlitz and Jena, when troops contended under the eyes and by the word of command of a few leaders, how much more so is it now, when the intelligent cooperation of every individual is required over a wider area of combat, wherein no man can raise his head to give or ask for any direction without the risk of getting a bullet through it.

Every British officer who came in contact with the Continental Contingents in China must have realised how different their tactical organisation, theory, and practice, are from ours; and the faith in offensive operations as opposed to the plan of awaiting the attack and submitting to the adversary's initiative, marks a dividing line between the ideas most in favour with the principal Continental Armies and the theories which just at present are fashionable with us.

It is a remarkable comment on these theories that we have never get been able to put them in practice. And so long as we aspire to compete for dominion with the rising Empires of the world, we must face the necessity of having an Army fit for offensive warfare. 